\title{
Hepcidin in Anemia and Inflammation in Chronic Kidney Disease
}

\author{
Jolanta Malyszko Michal Mysliwiec \\ Department of Nephrology and Transplantology, Medical University, Bialystok, Poland
}

\section{Key Words}

Hepcidin · Hepcidin, anemia $\cdot$ Hepcidin, inflammation • Chronic kidney disease $\cdot$ Iron balance, regulation .

Dialysis patients, anemia and iron balance

\begin{abstract}
Maintaining the correct iron balance is crucial for health. Our understanding of the molecular control of iron metabolism has increased dramatically over the past 5 years due to the discovery of hepcidin. This is a circulating antimicrobial peptide mainly synthesized in the liver, which has been recently proposed as a factor regulating the uptake of dietary iron and its mobilization from macrophages and hepatic stores. Inflammation causes an increase of production of hepcidin, which is a potent mediator of anemia of chronic diseases. Anemia in chronic kidney disease is mainly due to erythropoietin deficiency but these patients often have a chronic inflammatory state. The aim of this review is to summarize the current knowledge dealing with a possible role of hepcidin in iron metabolism and its regulation, particularly in kidney disease. In addition, current methods of determination of hepcidin are reviewed. Copyright $\odot 2007$ S. Karger AG, Basel
\end{abstract}

This invited review was supported by an unrestricted educational grant provided by Amgen. (c) 2007 S. Karger AG, Basel

$1420-4096 / 07 / 0301-0015 \$ 23.50 / 0$

Fax +41613061234 E-Mail karger@karger.ch www.karger.com

\section{Regulation of Iron Balance}

Iron is the fourth most common element in the Earth's crust and the most abundant transition metal in the human body. It is an essential element required for growth and survival. Virtually all life forms are exploiting this metal's unique chemical properties, namely its capacity to either accept or donate electrons, which are essential for crucial biochemical reactions. Moreover, iron is required for catalytic enzymes and protein crucial for DNA synthesis, transport of oxygen in hemoglobin and myoglobin, transport of electrons, cell respiration, oxidative phosphorylation, tricarboxylic acid cycle and many other biochemical pathways. However, iron is virtually insoluble under conditions occurring in our cells and body fluids. Moreover, excess free iron is toxic to the cells due to its ability to catalyze free radical generation. Hence, all living organisms have evolved sophisticated mechanisms to maintain appropriate iron levels in their cells and within their body. Therefore, since maintaining the correct iron balance is crucial to good health, specialized transport system and membrane carriers have evolved in humans to maintain iron in a soluble state that is suitable for circulation into the blood and transfer across cell membranes. Additionally, the absence of a physiological excretion mechanism requires organism iron homeostasis to be regulated by iron absorption from the intestine and the recycling of iron from senescent red blood cells [1-4]. 


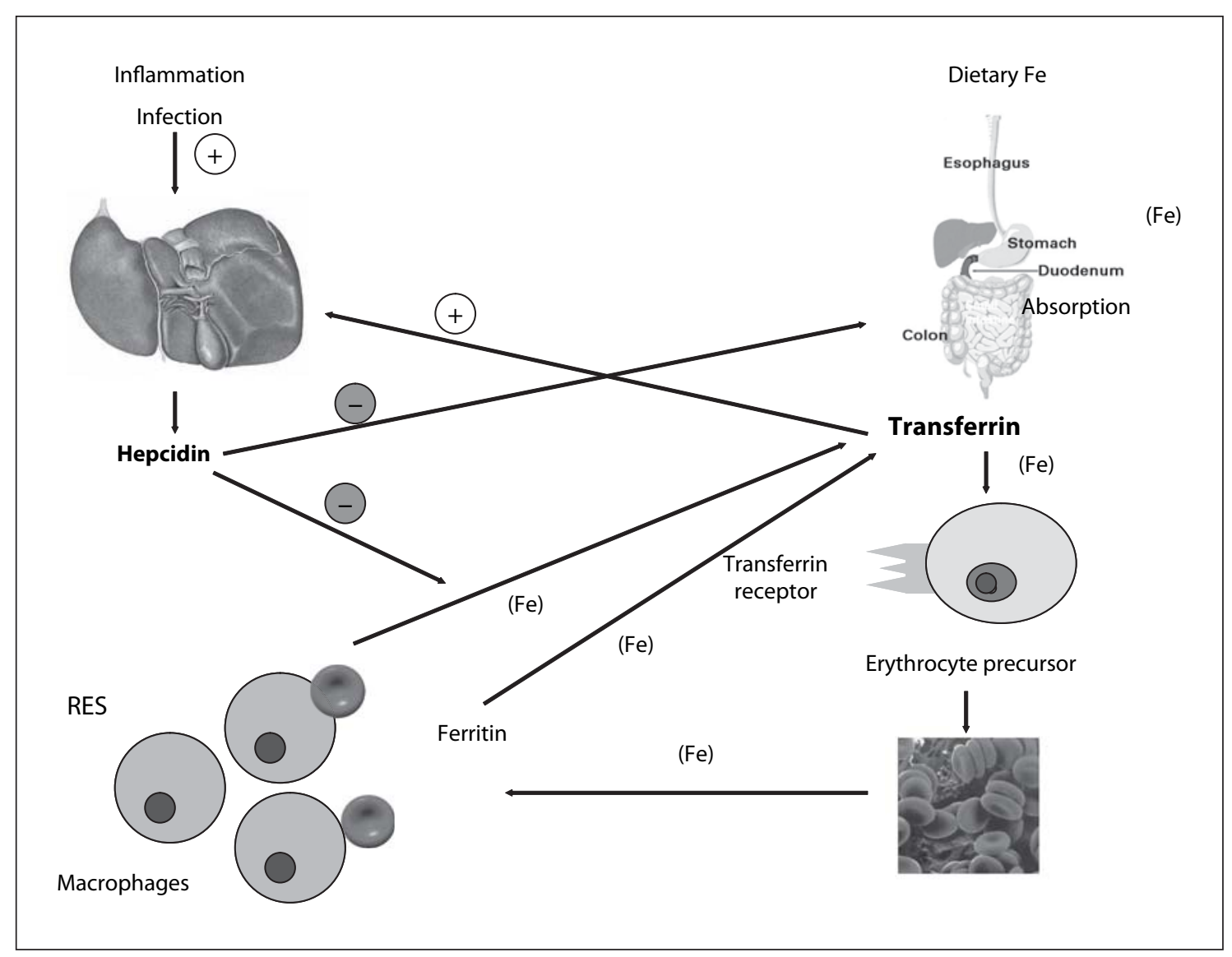

Fig. 1. Regulation of iron metabolism.

The intestinal iron absorption is modulated in response to the level of the iron body stores and by the amount of iron needed for erythropoiesis. This regulation is thought to operate through two regulators: store regulator and the erythroid regulator [5]. The understanding of the complexity of iron metabolism has increased substantially during the last decade although the signaling pathways and molecular components involved in the regulation of iron absorption through these two regulators have remained largely unknown. However, a tight control is posed on body iron homeostasis and trafficking iron acquisition as its utilization and storage must be finely tuned and optimized, mostly to satisfy the needs of erythrocyte precursors for synthesis of hemoglobin [6].

The regulation of iron metabolism involves the interaction of a number of specific proteins as well as the interplay between iron absorption and iron loss [1] (fig. 1). Our current understanding of iron metabolism and its deficiency is based upon the biology of a number of critical proteins. Well known are: transferrin (measured in the laboratory as the total iron-binding capacity - TIBC), transferrin receptor and ferritin (the cellular storage protein for iron and an acute-phase reactant) [2]. The newest are: an intracellular reporter of iron status, the iron-responsive element-binding protein (IRE-BP), which is also called iron regulatory protein or factor (IRP or IRF), HFE, mutations of which are responsible for hereditary hemochromatosis, divalent metal transporter (also known as DMT1, Nramp2, DCT1, solute carrier family 11, member 2 (Slc1la2)), the duodenal iron transporter SFT, a stimulator of iron transport, ferroportin and hephaestin-iron export proteins, and finally hepcidin, a possible negative regulator of intestinal iron absorption as well as macrophage iron release (fig. 2).

Normally, one-third of transferrin is saturated with iron (i.e. Fe/TIBC equals 33\%) [6, 7]. Transferrin saturation (TSAT) is decreased when iron supply to the plasma from macrophages and other storage sites is reduced, i.e. iron deficiency anemia, anemia of chronic inflammation (disease), and in some cases of ferroportin mutations. On 


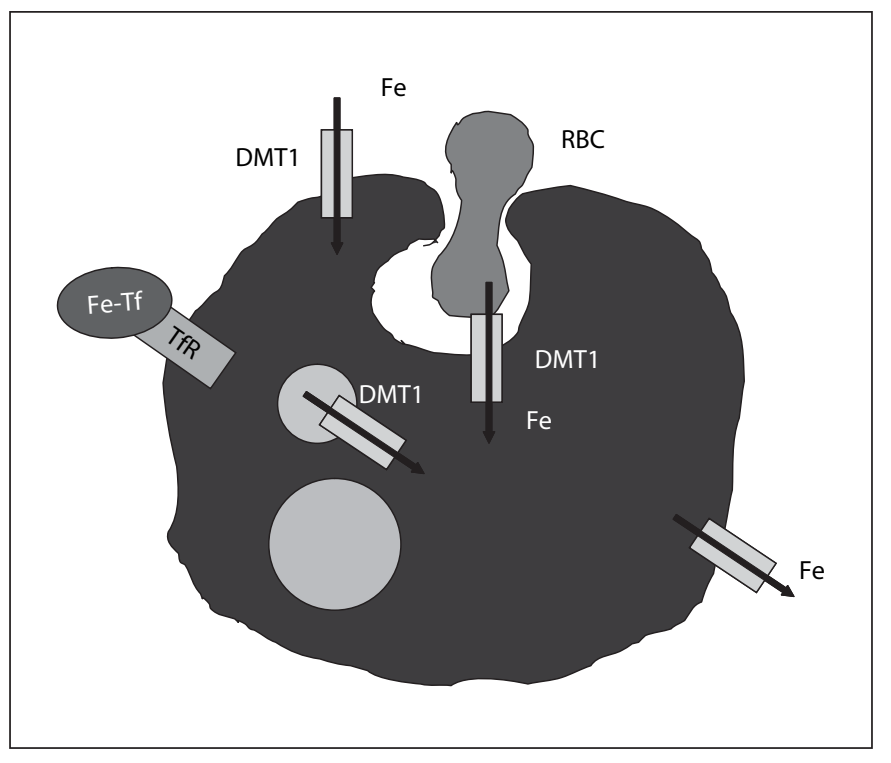

Fig. 2. Mechanisms of action of hepcidin: role of ferroportin.

the other hand, TSAT is increased when iron supply exceeds its demand, i.e. aplastic, sideroblastic anemia, hemochromatosis, liver disease and other forms of ineffective erythropoiesis. Transferrin receptors are present in hepatocytes and epithelial cells of the small intestine, including duodenal crypts [8]. They probably contribute to the body's iron sensing [9-11]. Each receptor can bind two transferrin molecules and, after their endocytosis, iron is offloaded (four $\mathrm{Fe}^{3+}$ atoms) in acidified vacuoles. Then the complex of the apotransferrin and transferrin receptor is recycled on the cell surface and released into circulation [12].

Ferritin is the cellular storage protein for iron. Ferritin is also an acute-phase reactant, and, along with transferrin and the transferrin receptor, is a member of the protein family that orchestrates the cellular defense against stress and inflammation $[13,14]$. The serum level of ferritin generally reflects overall iron storage, with $1 \mathrm{ng}$ of ferritin per $\mathrm{ml}$ indicating $10 \mathrm{mg}$ of total iron stores [15].

Ferroportin has been found to be strongly expressed in enterocytes, macrophages, and placental syncytiotrophoblasts $[16,17]$. It is a major iron transporter out of the cells. It transports iron from the mother to the fetus, transfers absorbed iron from enterocytes into the circulation and participates in the recycling of iron from senescent erythrocytes into macrophages and from them into the circulation. Ferroportin is upregulated by the amount of available iron [18, 19], and downregulated through its interaction with hepcidin [19-22].

Hepcidin in Anemia and Inflammation in Chronic Kidney Disease
It is generally accepted that iron homeostasis is mainly controlled by absorption of dietary iron in the gastrointestinal tract. The rate of iron absorption is regulated by body iron stores, bone marrow erythropoietic activity, hemoglobin concentration, blood oxygen saturation and the presence of systemic inflammation. Dietary iron is trivalent; therefore, it must be reduced by ferrireductase (most likely Dcytb) before it may be bound to a divalent metal transporter (DMT1) across a brush border membrane of enterocyte [23]. Then, iron is transported across a basolateral membrane of enterocyte by a membrane transporter ferroportin/Ireg1 into the circulation [23]. Ferroportin in enterocytes, macrophages and hepatocytes is downregulated by hepcidin. In the plasma, iron is bound to transferrin.

The normal iron content of the human body is about 3-4 g, predominantly in a form of hemoglobin in circulating erythrocytes (approx. $2.5 \mathrm{~g}$ ), iron-containing proteins such as: myoglobin, cytochromes, catalase (about $400 \mathrm{mg}$ ), bound to transferrin (3-7 mg) [1]. The remainder is storage iron in the form of ferritin or hemosiderin. The daily iron requirements for erythropoiesis are about 20-25 mg. It comes largely from macrophages, which have phagocytosed senescent erythrocytes [24]. In males the storage pool of iron is about $1 \mathrm{~g}$ (mainly in the liver, spleen and bone marrow). Due to menses, deliveries, pregnancies, etc., adult females have less stored iron. Western diet contains about $15 \mathrm{mg}$ of iron, some of this is heme iron, of which about $30 \%$ is promptly absorbed, probably via heme carrier protein $1[5,7]$. The remaining iron, which accounts for almost all iron in non-Western diet, is poorly absorbed, with less than $10 \%$ being taken into the mucosal cells. Diets rich in fish, poultry and meat (i.e. rich in heme iron) have higher bioavailability than vegetarian diets (30 vs. 10\%). Iron from non-animal sources, i.e. cereal, breads, fruits, vegetables, is absorbed better in the presence of ascorbic acid, whereas teas (rich in tannates), bran foods rich in phosphates, and phytates inhibit iron absorption. Daily about $1-2 \mathrm{mg}$ of iron is absorbed (i.e. $30 \%$ of $1-2 \mathrm{mg}$ of heme iron in the Western diet and about $10 \%$ of $10-15 \mathrm{mg}$ of non-heme iron). Thus, iron homeostasis is regulated strictly at the level of intestinal absorption. Iron stores control the rate of iron absorption, on the other hand, mobilferrin in the intestinal cells can hold onto iron in the iron replete state [2]. When mucosal cells are sloughed, this iron is lost [2]. There is no specific mechanism of iron excretion from the human body. Iron is lost in sweat, shed skin cells, and perhaps some gastrointestinal loss at a rate of approximately $1 \mathrm{mg} /$ day. In addition, in females, there is a menstrual iron loss

Kidney Blood Press Res 2007;30:15-30 
of 1-2 mg daily. Hence, only a small amount of iron enters and leaves the body on a daily basis. Most iron is recycled from the breakdown of senescent erythrocytes by macrophages of the reticuloendothelial system.

However, it has been shown recently that the kidney is also involved in iron metabolism. Hepcidin, a recently discovered small, cysteine-rich cationic peptide, was isolated from human urine [25] and blood [26]. Kulaksiz et al. [27] suggest that the kidneys, besides the liver, are involved not only in the synthesis, but also may participate in the hepcidin elimination as well. Moreover, there is abundant expression of Nramp2 (DCT1) in the proximal tubule and collecting ducts of the kidney [28]. This raises the possibility that in the kidney there is an iron excretory pathway, counteracted by its constitutive reabsorption.

\section{Anemia and Iron Balance in Dialysis Patients}

Anemia has remained one of the most characteristic and visible manifestations of chronic renal failure for over 150 years. Typically, it is a normocytic and normochromic anemia with bone marrow of normal cellularity. The pathogenesis of anemia of chronic kidney disease is multifactorial. Although inadequate production of erythropoietin is the most important factor in the pathogenesis of anemia in chronic kidney disease, other factors play a role and contribute to mild anemia that is often present despite the use of recombinant human erythropoietin or other erythropoiesis-stimulating agents (ESA). The main ones among them are shortened erythrocyte survival, blood loss, iron and other nutritional deficiencies, hemolysis, and the presence of uremic inhibitors of erythropoiesis.

Adequate iron stores are essential for achieving maximum benefit from the ESA therapy. Normally, three quarters of a body's iron is present in circulating erythrocytes, and one quarter is stored mainly in the liver and bone marrow. Because the demand for iron by the erythroid marrow frequently exceeds iron stores once ESA therapy has been initiated, iron supplementation is essential. In the era before erythropoietin therapy was available, advanced kidney disease and its associated hypoproliferative anemia were frequently accompanied by excess iron due to frequent blood transfusions. Now iron overload is uncommon, whereas iron deficiency has become more common. Iron deficiency blunts erythropoiesis and impairs response to erythropoietin. The blood losses from low-level gastrointestinal bleeding, repeated phlebotomy for laboratory tests, and from blood trapping in the dialyzers can amount to $10-20 \mathrm{ml}$ per treatment [29]. Hemodialysis patients lose an average of $2 \mathrm{~g}$ of iron per year or up to 1.5-3 1 of blood [29]. Thus, iron deficiency will develop in virtually all dialysis patients receiving recombinant human erythropoietin or darbepoetin alfa, unless supplemental iron therapy is instituted.

An important issue in the diagnosis of iron deficiency in dialyzed patients is that the laboratory criteria are markedly different from those in persons with relatively normal renal function. Absolute iron deficiency is likely to be present in end-stage renal disease when TSAT falls below $20 \%$ and the serum ferritin concentration is $<100 \mathrm{ng} / \mathrm{ml}$ [30]. In normal subjects these values of ferritin are within the normal range. These discrepancies in ferritin concentration between normal subjects and dialyzed patients are partly due to the fact that ferritin is an acute-phase reactant and chronic kidney disease and the dialysis therapy are subclinical inflammatory states.

It is now recognized that a functional iron deficiency may exist among patients with renal failure; this is characterized by the presence of adequate iron stores as defined by conventional criteria, but with the inability to sufficiently mobilize this iron to adequately support erythropoiesis with the administration of erythropoietin. In this setting, an inadequate amount of iron is released from the liver and other storage sites. Among such patients, the serum ferritin level is either normal or elevated, but the TSAT typically falls to about $20 \%$ or below. It is clinically important to distinguish functional iron deficiency, which usually responds to iron therapy, from inflammatory iron block, which does not. The inflammatory iron block occurs among patients with refractory anemia due largely to an underlying inflammatory state. Unfortunately, with both functional deficiency and inflammatory block, the TSAT is less than $20 \%$ and the ferritin level is elevated (between 100 and $800 \mathrm{ng} / \mathrm{ml}$ ). In patients with acute or chronic inflammatory conditions the diagnosis of iron deficiency or functional iron deficiency is particularly challenging because most of the biochemical markers for iron metabolism are affected by the acute-phase reaction. The response to erythropoietin or parenteral iron may help distinguish among these two possibilities. In patients with functional deficiency, but not with inflammatory iron block, ferritin levels may decrease with erythropoietin administration. Inflammatory block is also most likely present if the administration of intravenous iron is associated with a progressive increase in ferritin concentration rather than with increased erythropoiesis [31]. 


\section{Hepcidin}

\section{Structure}

Hepcidin, a recently discovered small, cysteine-rich cationic peptide, was isolated independently by two groups searching for novel antimicrobial peptides. In 2000, Krause et al. [26] isolated a novel peptide from plasma. Since it was produced by the liver and had antimicrobial properties, it was named liver-expressed antimicrobial peptide-1 (LEAP-1), whereas Park et al. [25] isolated this peptide from human urine and designated it as hepcidin (hepatic bactericidal protein). As reviewed by Ganz [32], the structure of hepcidin is highly conservative among mammals, suggesting a key role in major biological functions. Closely related hepcidin sequences are found in vertebrates from fish to humans. Hepcidin connections to iron metabolism were disclosed by Nicolas et al. [33] and Pigeon et al. [34]. Nicolas et al. [33] identified that the murine gene hepcidin had a role in iron metabolism totally serendipitously. They worked on glucose metabolism-related transcription factor USF2 (upstream stimulatory factor 2) knockout mice, which unexpectedly were iron overloaded. It was found that instead of the USF2 gene, the hepcidin gene was disrupted in these mice, whereas Pigeon et al. [34] searching for iron upregulated genes, discovered that murine hepcidin mRNA expression was increased by iron overload and decreased by iron depletion.

Hepcidin is a product of a 2.5 -kb HAMP gene, consisting of three exons and two introns, located on the long arm of chromosome 19 (NCBI Gene ID 57817). Humans and rats have a single HAMP gene, whereas mice have two functional genes. The gene transcribes into a $0.4-\mathrm{kb}$ mRNA, which is translated into a precursor protein of 84 amino acids including a putative 24 amino acid leader peptide. After a cleavage of the 24 amino acid $\mathrm{N}$-terminal signal peptide, prohepcidin is transported through the hepatocyte basolateral membrane into the circulation. The major circulating bioactive forms of hepcidin consist only of the carboxy-terminal portion (peptides of 25, 22 and 20 amino acids) $[34,35]$. The exact location of the final prohormone processing is unknown. Propeptide convertases could be located in the blood or in the cell membrane of capillaries. There is still no reliable information available on normal serum levels of mature hepcidin (20, 22 and 25 amino acids). However, 60 amino acid prohepcidin is easily detectable in serum [27]. Hepcidin-25, the major form of mature hepcidin, is cleaved from prohepcidin by convertases. Hepcidin-20 and hepcidin- 22 may be directly generated from prohepcidin by convertases or indirectly by degradation of hepcidin- 25 . Hepcidin-25 has both iron-regulatory and antimicrobial properties; hepcidin-22 has a potent antimicrobial activity in vitro, but no iron-regulatory function of hepcidin20 has been identified $[21,25]$. Hepcidin-25 and hepcidin-20 are a major form of hepcidin in urine, while hepcidin-22 is a minor one [25]. The same may be true for serum.

As revealed by nuclear magnetic resonance spectrometry [35], cysteine-rich hepcidin forms a simple hairpin stabilized by four disulfide bonds, but one of these is an unusual vicinal disulfide bond in the turn [35]. The nuclear magnetic resonance structure studies indicated that hepcidin-20 exists as a monomer, whereas hepcidin-25 readily aggregates [35].

\section{Production}

Hepcidin is expressed predominantly in the liver, but lower expression was also detected in the kidney, heart, skeletal muscles and brain. Hepcidin-expressed sequence tags were also detected in lungs, stomach and pancreas. Kulaksiz et al. [27] indicated that the highest hepcidin concentration in the liver was in the periportal region of hepatocytes, which decreases towards central veins and sinusoids. It is consistent with hormonal-type regulation. Moreover, it has been suggested that the kidneys are not only involved in the synthesis of hepcidin, but may also be involved in the elimination of this peptide. In another work, Kulaksiz et al. [36] reported that hepcidin was produced as an intrinsic peptide in the epithelial cells of the tubule and collecting duct in mammalian kidney and may also be released luminally into the urine. Localization of hepcidin in the kidney implicates an iron-regulatory role of this peptide hormone in the renal tubular system, possibly in connection with the iron transporter DMT1. DMT1 expression has been shown to be highest at the apical pole of epithelial cells of distal tubules and collecting ducts, where hepcidin was also found. Kulaksiz et al. [36] suggested that hepcidin is involved in a sophisticated regulation of renal iron transport and their RT-PCR experiments show that hepcidin was intrinsically produced in the kidney.

\section{Mechanism of Action}

Substantial progress has been made to elucidate the mechanism of action of hepcidin. Presently, the main hepcidin function is homeostatic regulation of iron metabolism and mediation of host defense and inflammation. The first link between hepcidin and iron metabolism came from the study of Pigeon et al. [34] and Nicolas 


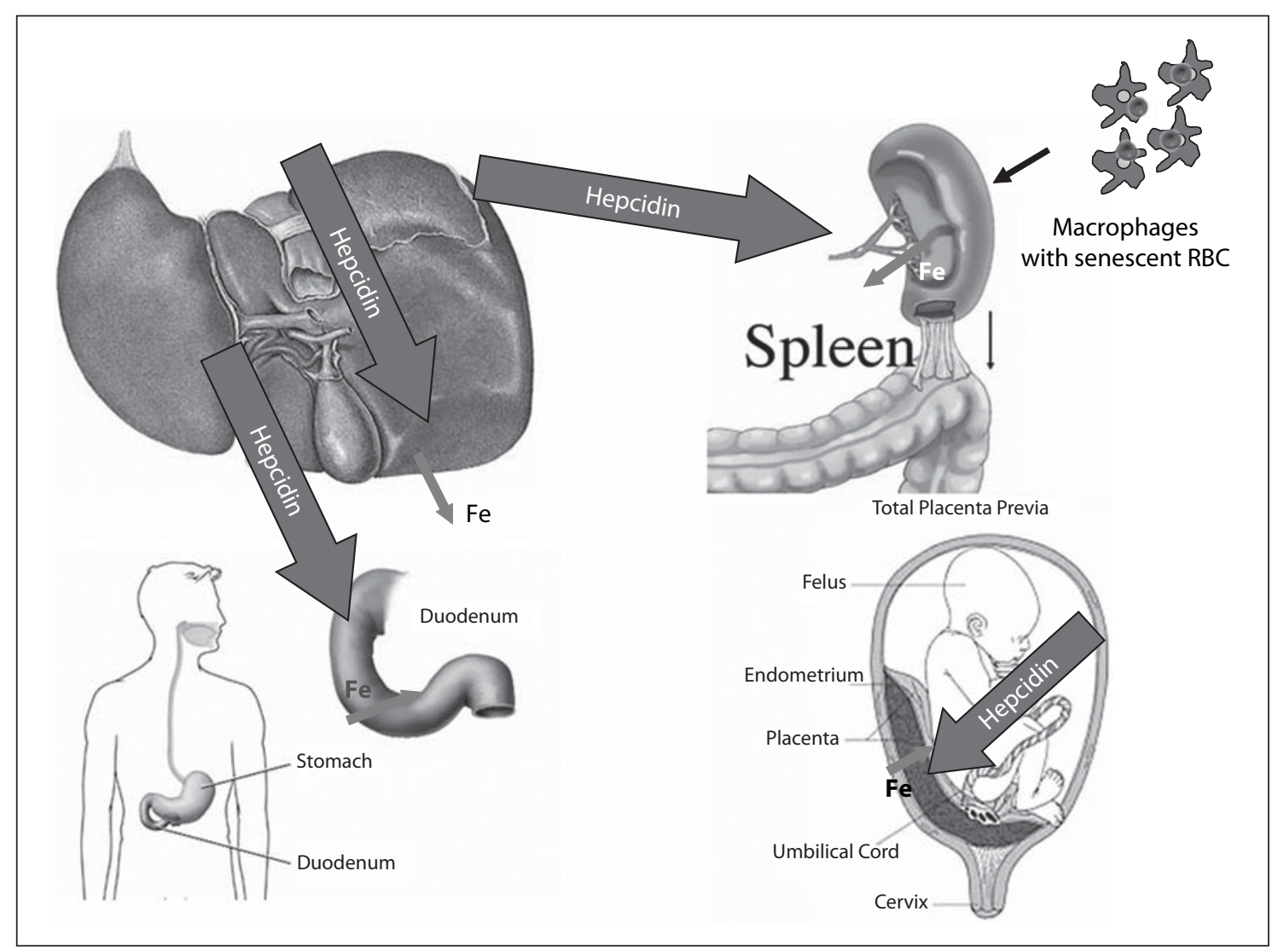

Fig. 3. The main function of hepcidin.

et al. [33]. The hepcidin gene was overexpressed in livers of experimentally iron-loaded mice [37]. The study also showed that hepcidin knockout mice developed iron overload [33,37]. They concluded that constitutive overexpression of hepcidin inhibits the iron accumulation normally observed in HFE-deficient mice [37, 38]. Injection of hepcidin inhibited intestinal iron absorption in mice independent of their iron status and did not require the HFE gene product [39]. Rivera et al. [21] showed that hepcidin injection results in a dose-dependent in serum iron. Conversely, iron ingestion in humans induced hepcidin secretion in urine [40]. These observations suggest that hepcidin plays a role as a negative regulator of intestinal iron absorption and iron release from macrophages (fig. 3). Evidence from transgenic mouse models indicates that hepcidin is the predominant negative regulator of: iron absorption in the small intestine, iron transport across the placenta, and iron release from the macrophages [32]. Hepcidin controls intestinal iron absorption by regulating ferroportin expression on the basolateral membrane of enterocytes [41]. Hepcidin directly regu- lates the expression of the ferroportin on cell membranes, acts by binding to the cellular iron exporter ferroportin and inducing its internalization and degradation, thus trapping iron in enterocytes, macrophages and hepatocytes. The net effect of hepcidin is the diminished absorption of dietary iron, sequestration of iron in macrophages and sequestration of iron in hepatic stores. The absence of hepcidin synthesis would naturally lead to a major loss of control over iron release by enterocytes and macrophages followed by circulatory iron overload. Hemojuvelin is probably a key modulator of hepcidin expression. Hemojuvelin generates bone morphogenic protein, which increases hepcidin mRNA levels.

\section{Hepcidin and Anemia}

Most of the iron absorbed from the diet or recycled from hemoglobin is destined for red blood cell production. Nicolas et al. [42] found that the gene encoding the hepcidin is regulated by anemia, hypoxia and inflamma- 
Fig. 4. Hepcidin feedback mechanism.

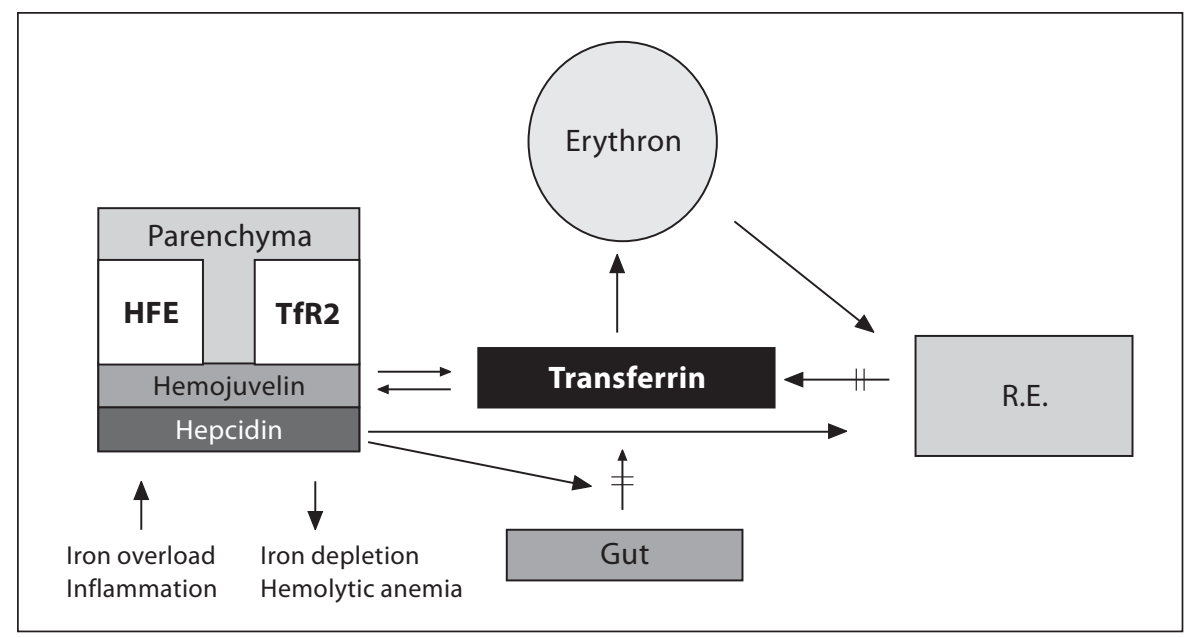

tion. Anemia and hypoxia decrease liver hepcidin expression [42]. The same study showed that downregulation of hepcidin synthesis can be triggered by hypoxia alone, and mice housed in hypobaric hypoxia chambers simulating an altitude of 5,500 $\mathrm{m}$ also showed a rapid decrease in hepcidin [42]. Many enzymes in oxygen-utilizing pathways are iron-dependent: thus, low iron content in the organism mimics hypoxia. Experimental inflammation dramatically increases hepcidin expression and reduces serum iron [42]. Hypoxia is a primary signal regulating erythropoietin production by the liver in the fetus and the kidney in the adult. It was reported that erythropoietin downregulated the liver hepcidin gene expression [43]. Erythropoietin was directly injected to C57BL/6 mice for 3 days. After that, hepcidin gene expression was assessed by Northern blot analysis and compared to saline-injected control mice. Mice treated with erythropoietin increased hematological indices and splenomegaly consistent with increased erythropoiesis. Injection of erythropoietin was found to dramatically decrease liver hepcidin gene expression as compared to saline-injected control mice, thus mimicking the effects of hypoxia. These results suggest that hypoxia acts on both erythropoiesis induction and hepcidin gene downregulation through erythropoietin [43].

In anemia, when oxygen delivery is inadequate, there is a need to produce more erythrocytes. Anemia induced by phlebotomy, or by hemolysis (from phenylhydrazine), suppresses hepatic hepcidin mRNA [42]. A decrease in hepcidin enables more iron to be absorbed from the gut and from the stores in hepatocytes and macrophages. The hepcidin promoter contains several binding sites for hypoxia-inducible factor (HIF), and it is possible that the mechanisms of hypoxic regulation of hepcidin will turn out to be transcriptional, via the common oxygen-sensing regulatory pathway [44]. In addition, the hepcidin gene promoter also contains binding sites for STAT-signal transducer and activator of transcription, the hepatocyte nuclear factor 4 and C/EBP (enhancer-binding proteins which control proliferation and differentiation of various cells) [45].

In conclusion, hepcidin is an acute-phase protein, produced in the liver, which appears to be directly involved in iron metabolism (fig. 4). On the other hand, hepcidin may serve as an important mediator in the pathogenesis of the anemia of chronic disease [46] and hereditary hemochromatosis [47]. Most studies confirming the role of hepcidin in iron metabolism have been performed in experimental animals. Institution of an iron-free diet, production of the anemic state, and hypoxia are associated with decreased hepcidin production, while increased hepcidin production is noted in acute inflammation [32, 42]. Hepcidin is an acute-phase protein that is synthesized to restrict the body's iron stores, to prevent iron being requisitioned by invading microorganisms, but this does not explain how it respond to the body's iron needs. It is possible that this missing link involves hypoxia.

\section{Hepcidin and Inflammation}

As mentioned previously, the gene encoding hepcidin is also regulated by inflammation [42]. Hepcidin, produced by the liver, constitutes an important link between iron metabolism, host defense and inflammation. In hu- 
mans, the liver is central in the innate immune response and it is responsible for the increased synthesis of many proteins called 'acute-phase proteins', which are involved in host defense. Acute-phase proteins are defined as those proteins whose plasma concentrations increase (positive acute-phase proteins) or decrease (negative acute-phase proteins) by at least $25 \%$ during inflammatory states [48]. These changes largely reflect their production by hepatocytes. The acute-phase response is a major pathophysiologic phenomenon that accompanies inflammation [49, 50]. With this reaction, normal homeostatic mechanisms are replaced by new set points that presumably contribute to defensive or adaptive capabilities. The acute-phase response accompanies both acute and chronic inflammatory states, including infection, trauma, infarction, inflammatory arthritides, and neoplasms. It was Pigeon et al. [34] who in 2001 reported that hepcidin expression is increased by lipopolysaccharide (LPS). LPS induced the synthesis of several acute-phase proteins. Hepcidin synthesis is markedly increased during infection and inflammation [34, 42, 51, 52] and reduces serum iron [42]. During the inflammatory process the following cytokines are primarily produced by macrophages and monocytes: interleukin (IL)-6, IL-1 $\beta$, tumor necrosis factor- $\alpha$ (TNF- $\alpha$ ), interferon- $\gamma$, and transforming growth factor (TGF)- $\beta$. They stimulate acute-phase protein production, with IL- 6 being the major inducer of the majority of acute-phase reactants [53]. This family of cytokines also suppresses hepatic albumin synthesis [54]. Nemeth et al. [40] reported that IL-6 is apparently a key inducer of hepcidin synthesis during inflammation, whereas IL-1 or TNF- $\alpha$ did not affect hepcidin synthesis. In the recent report, Wrighting and Andrews [55] showed that the inflammatory cytokine IL-6 directly regulated hepcidin through induction and subsequent promoter binding of signal transducer and activator of transcription 3. STAT3 was necessary and sufficient for the IL- 6 responsiveness of the hepcidin promoter. Their findings provide a mechanism by which hepcidin can be regulated by inflammation or, in the absence of inflammatory stimuli, by alternative mechanisms leading to STAT3 activation. Hepcidin is consistent with a type II acute-phase protein [51]. Injection of turpentine, besides LPS as a standard inflammatory stimulus, into mice resulted in a marked decrease in serum iron [40, 42], whereas in hepcidin and IL-6-deficient mice this response was completely ablated. In humans injected with LPS, a dramatic increase in IL-6 was observed with a peak at 3-4 h [55]. It was associated with maximal hepcidin excretion observed at $6 \mathrm{~h}$, and the onset of hypoferremia [56]. Moreover, in humans, IL-6 in- fusion resulted in a hepcidin increase together with hypoferremia and a fall in TSAT by more than 30\% [40]. Hypoferremia develops within hours of the inflammatory stimulus. The growth and metabolism of many microorganisms is exquisitely iron-sensitive [57]. Bacteria require iron for the production of the superoxide dismutase that protects them from host oxygen radicals [58, 59]. However, the iron concentration in the environment or in the host is too low to sustain the optimal conditions for invading microorganisms. Both bacteria and the host mechanisms have to tackle with this problem. Bacteria developed siderophores (high-affinity iron-binding molecules) retrieving iron from transferrin or lactoferrin of the host. The host also developed defense mechanisms such as increased production of iron-binding proteins (i.e. transferrin), fall in dietary iron absorption, raise in iron-storing proteins, release of apolactoferrin from neutrophils to sequester the iron at the site of invading microorganisms. Hepcidin, by inducing sequestration of iron in macrophages, robs bacteria of this element. Blood and intracellular bacteria may weaken and biofilms may not develop [60]. Defensins are antimicrobial peptides produced by cells of epithelial lining [61]. Hepcidin, like other defensins, is an antimicrobial peptide killing them on contact. However, because it is produced by the liver, it has not been found to have chemotactic properties, and differs structurally from other defensins [35]. Therefore, hepcidin wards off infections, in part as a defensin (it possesses antimicrobial activity), acute-phase protein [51] and by causing hypoferremia [62]. Moreover, hepcidin could be a key defense mechanism in the 'evolutionary oversight' according to Ashrafian [63] due to its role in iron metabolism. It is well known that iron can be toxic, since it catalyzes the generation of free oxygen species [58] and activated NF- $\kappa \mathrm{B}$, the prototypic transcription factor for genes involved in inflammation [64]. In the mouse hepcidin gene a NF- $\kappa \mathrm{B}$ binding site has been identified. Since inflammation is known to induce hepcidin synthesis, this finding stresses the link between hepcidin and inflammation [65]. Hence, during inflammation, infection [32] and possibly also in cancer [66], elevated hepcidin results in decreased iron release from enterocytes, hepatocytes and macrophages. It leads to the fall in serum iron and diminished availability of iron for bacteria and tumor cells. Since elevated hepcidin levels were reported in some cases of hepatic adenoma [66], hepcidin upregulation could also be a universal mechanism inducing iron starvation of tumor cells. However, in the long term this hypoferremia induced by hepcidin could result in anemia of chronic disease [40,67]. 


\section{Hepcidin and Anemia of Chronic Disease/ Inflammation}

The anemia of chronic disease (ACD), also termed the anemia of chronic inflammation, was initially thought to be associated primarily with infectious, inflammatory, or neoplastic disease. However, other observations have shown that ACD can be observed in a variety of conditions, including severe trauma, heart disease, diabetes mellitus, and in patients with acute or chronic immune activation [68-73]. Anemia is typically normochromic, normocytic, and hypoproliferative. The pathogenesis of ACD involves decreased red cell survival, blunted erythropoietic response to anemia, and disturbances in iron metabolism, i.e. impaired iron delivery to erythroid precursors due to reduced iron absorption and decreased macrophage iron recycling. The low serum iron, normal to low TIBC, associated with high to normal ferritin in patients with inflammation, has been perplexing. In the modern world, after man's entry into the age of antibiotics, ACD is now perhaps more aptly named anemia of inflammation. The molecular basis for ACD is not fully understood. Cytokines and acute-phase proteins affect regulation in iron homeostasis in ACD. In 2002, Nicolas et al. [42] discovered that the gene encoding hepcidin was regulated in response to anemia, hypoxia and inflammation. This link between hepcidin and ACD was presented by Fleming and Sly [74]. Hepcidin is an acute-phase reacting protein, which may mediate the changes in iron metabolism observed during inflammation. Evidence from transgenic mouse models indicates that hepcidin is the predominant negative regulator of iron absorption in the small intestine, iron transport across the placenta, as well as iron release from macrophages [32]. IL-6 is required for the induction of hepcidin and hypoferremia during inflammation in both animals and humans. Therefore, Nemeth et al. [51] suggested that hepcidin is a key mediator of ACD. In addition to serum iron concentration and inflammation/ infection, anemia also affects hepcidin levels. Together with hypoxia, anemia overrides the effect of iron and inflammation, decreasing hepcidin mRNA $[42,66]$. During inflammation, high hepcidin would result in fall in hematocrit. The downregulation of hepcidin mRNA by anemia results in a new steady state with hematocrit decreased by $3-5$ points below baseline.

The pathogenesis of anemia of inflammation could be, at least partly, explained by disturbances in iron metabolism. Erythrocytes synthesis is highly dependent on iron availability. More than half of the iron is bound to hemoglobin. Plasma transferrin compartment contains only about $3 \mathrm{mg}$ of iron. Iron bound to transferrin is the primary source for hemoglobin synthesis in erythroid precursors. Transferrin serves as a transit compartment for about $20 \mathrm{mg}$ of iron each day, predominantly recycled from senescent red blood cells and destined for erythropoiesis. The major iron recycling pathway consists of the degradation of senescent erythrocytes by reticuloendothelial macrophages located in the bone marrow, hepatic Kupffer cells and spleen. The exit of iron from macrophages is controlled by ferroportin, which is regulated by hepcidin. When erythrocytes are lysed intracellularly to recover iron from heme, this recycled iron is finally exported from macrophages into the circulation and returned to transferrin. In normal conditions, serum iron turns every 3-4 h. Hence, if hepcidin could block iron recycling completely, a 25\% fall in serum iron should be observed within an hour. This acute response is probably aimed to eliminate invading microorganisms. Macrophages recycle 10-20 times more iron than the intestine can absorb. During inflammation, over time, hepcidin inhibits iron release from macrophages and enterocytes. Since most iron bound to transferrin is destined to bone marrow, hypoferremia results in a decrease in iron available for erythropoiesis. Anemia of inflammation develops as a side effect of the hypoferremic response to inflammation/infection. Moreover, in the recent study, Dallalio et al. [75] reported that hepcidin may contribute to the anemia of inflammation not only through effects on iron metabolism, but also through inhibition of erythroid progenitor proliferation and survival. Thus, we can speculate that this mechanism may contribute the blunted erythropoietic response to anemia (fig. 5).

Nemeth et al. [51] observed that urinary excretion of hepcidin increased significantly in patients with hypoferremia and anemia due to infections or inflammatory diseases. In human volunteers, IL-6 infusion caused hypoferremia (fall by $34 \%$ ) within $2 \mathrm{~h}$ and a 7.5 -fold increase in urinary hepcidin [40]. Transgenic mouse with IL-6 overexpression as well as patients with Castleman's disease and multiple myeloma, known to be associated with IL-6 excess, is anemic [76]. However, direct evidence of IL-6-induced anemia came from observations in oncology patients treated with recombinant anti-IL- 6 as an anti-tumor drug [77, 78]. IL-6 produced anemia within 3 days, with nadir of hypoferremia at 6 weeks. Dilutional anemia and hypoferremia resolved after cessation of IL- 6 treatment [78]. 


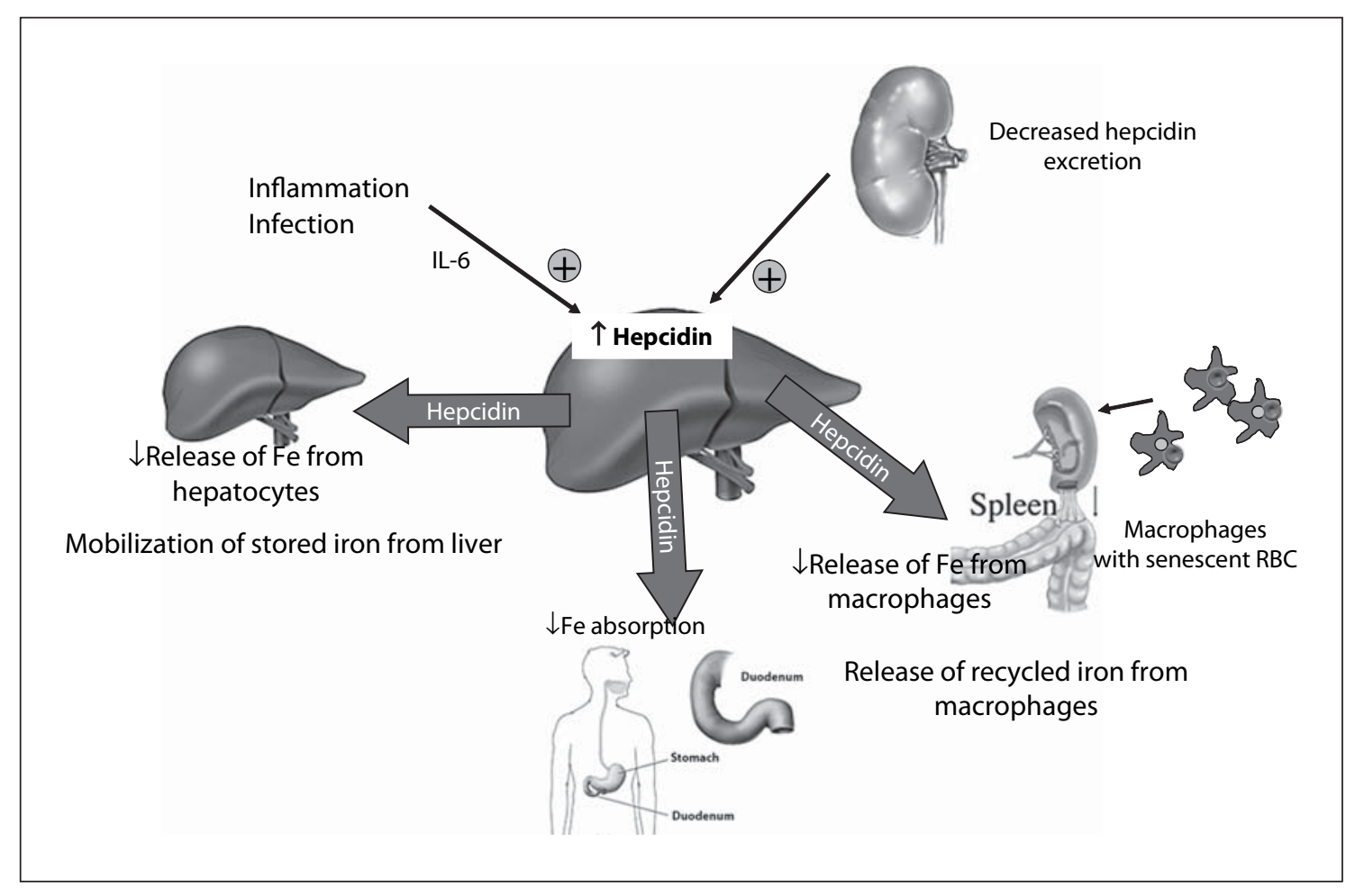

Fig. 5. Mechanism of the anemia of chronic disease and the role of hepcidin.

\section{Hepcidin and Anemia in Kidney Disease}

Anemia develops gradually during progressive decline in renal function with erythropoietin deficiency being by far the major cause. Shortened erythrocyte survival (due to hemolysis, bleeding, and increased oxidative stress) is a minor contributor. Over $90 \%$ of patients respond adequately to erythropoietin-stimulating agents (erythropoietin alfa, beta or darbepoetin-alfa). Patients with a chronic kidney disease have a chronic inflammatory state. This is due to many underlying factors, including an enhanced incidence of infections, the uremic milieu, elevated levels of proinflammatory cytokines, frequent presence of widespread arteriosclerosis, and others. There are additional factors on hemodialyses, which may contribute to this process (impure dialysate, bioincompatible dialysis membranes, intercurrent infections [79-85]. An increasing attention has focused on inflammation as a possible cause of the wasting syndrome in end-stage renal disease as well as anemia refractory to epoetin therapy. Deteriorating renal function may enhance overall inflammatory responses because of the decreased renal clearance of factors that are directly or indirectly involved in inflammation. As an example, the serum half-lives of proinflammatory cytokines, TNF- $\alpha$ and IL-1 are greater in animals without renal function [86]. A declining renal function may also affect the levels of additional inflammatory molecules, such as serum C-reactive protein (CRP) or IL-6, which are inversely correlated with creatinine clearance $[87,88]$. In addition, in dialysis patients with residual renal function, higher serum CRP concentrations are observed among those with relatively less native kidney function $[89,90]$. In renal failure, endothelial dysfunction and atherosclerosis as well as cardiovascular complications are almost universal. Inflammatory markers have been shown to play a role in the pathogenesis and progression of atherosclerosis, regarded as a chronic inflammatory condition [91]. Iron metabolism is disturbed in chronic inflammatory diseases, i.e. atherosclerosis [92]. Renal insufficiency alone is reported to be a risk factor for atherosclerosis and cardiovascular diseases. This may be due in part to concurrent inflammation. The diagnosis of iron deficiency or functional iron deficiency is particularly challenging in patients with acute or chronic inflammatory conditions because most of the biochemical markers for iron metabolism are affected by 
Fig. 6. Anemia in chronic kidney disease and the possible role of hepcidin.

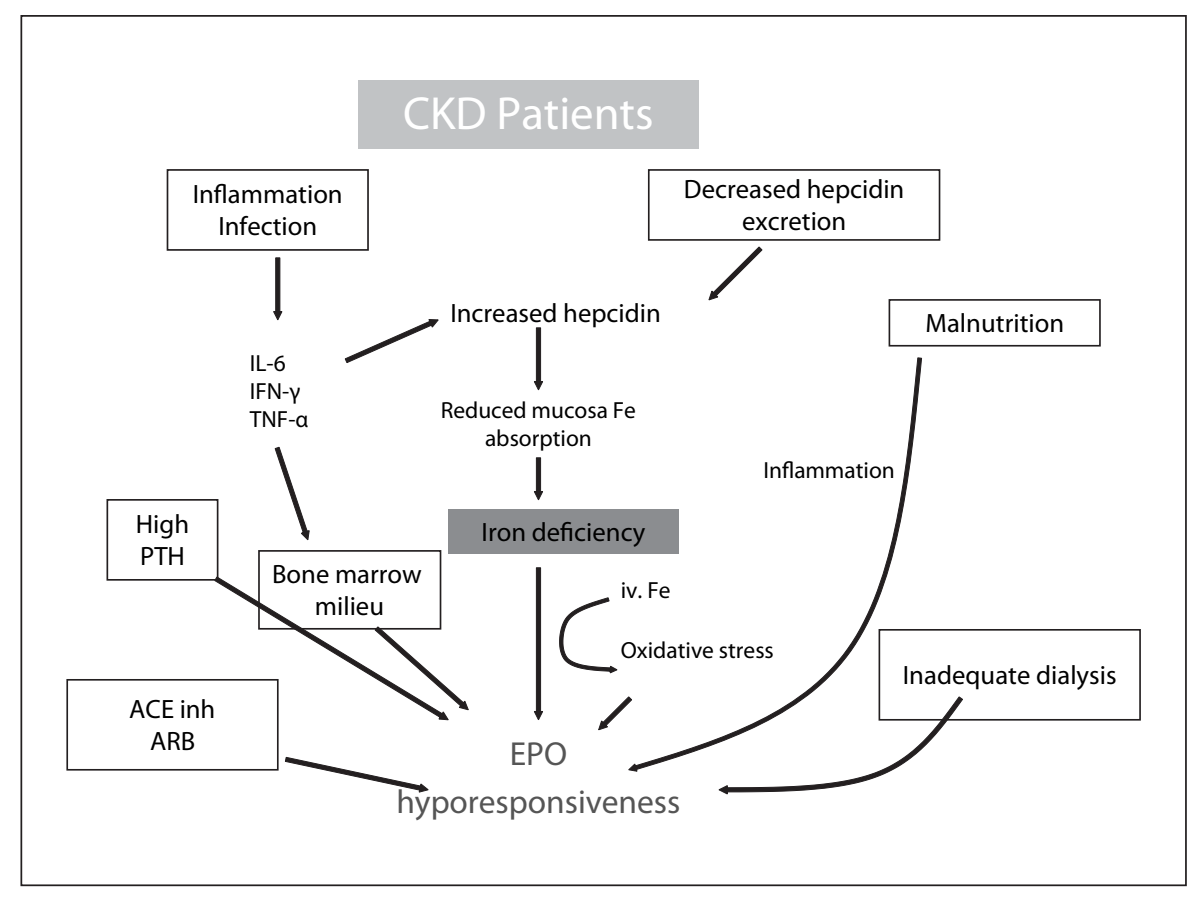

acute-phase reaction. Since patients with chronic kidney disease have a mild to moderate chronic inflammatory state, similar to that occurring in rheumatoid arthritis or malignancy, Allen et al. [93] put forward a hypothesis that patients requiring higher doses of erythropoietin may have greater 'inflammatory activity' and cytokine propagation. Hence, interactions of proinflammatory cytokines with hepcidin, mediating functional iron deficiency in such patients, might explain why these patients have high ferritin, poor iron absorption, and impaired iron release from macrophages (fig. 6). High levels of hepcidin (prohepcidin) have been found in patients with ACD [51] and in those with chronic renal failure and anemia [27, 36, 94-96]. Dallalio et al. [96] studied samples from patients evaluated for anemia and ferritin and found that serum hepcidin, measured using Western blot assay, was lower in patients with $\mathrm{ACD}(\mathrm{n}=8)$ than in patients with iron deficiency anemia. However, virtually no data is available about these patients (age, gender, creatinine, CRP, etc.). Only parameters of iron status and hepcidin were provided. The only correlation described in this study was between ferritin and hepcidin in anemia patients undergoing bone marrow examinations. Dallalio et al. [96] used serum specimens to detect 9-kDa prohepcidin, whereas Nemeth et al. [51] used urine specimens to detect $2-\mathrm{kDa}$ hepcidin. In the studies on patients with renal failure, ELISA prohepcidin assays were used [27, 36, 94, 95].

From the nephrologists' point of view, iron deficiency and chronic inflammation are two major and commonly encountered causes of hyporesponsiveness to exogenous erythropoietin. Patients with chronic renal failure treated with erythropoietin frequently exhibit functional iron deficiency, i.e. low TSAT together with normal or high serum ferritin [97]. At the same time, majority of them have elevated CRP levels [97]. Experimental data showed that inflammation-induced changes in hepatic hepcidin expression preceded the decrease in serum TSAT [98]. Moreover, hepcidin, either in serum or in urine, showed a strong correlation with serum ferritin in patients with anemia of inflammation [51]. Hepcidin correlated with hepatic iron stores and hemoglobin [99], but not with inflammation in patients with hepatitis C [100]. One may ask what the possible interaction between hepcidin and erythropoietin is. Injection of erythropoietin was found to dramatically decrease liver hepcidin gene expression in healthy mice as compared to saline-injected control mice [43]. Expression of the erythropoietin gene is controlled by oxygen-sensitive transcription factor HIF, and hepcidin promotor contains several binding sites for HIF [44]. In patients treated with exogenous erythropoietin, absolute iron deficiency develops rapidly, unless supple- 
mented. In chronic kidney disease, hepcidin levels remained persistently high, probably due to decreased excretion, chronic inflammatory state or, as suggested recently [101], due to induction of hepcidin expression by dialysis and/or insufficient removing by dialysis. Iron absorption remains inadequately low in dialysis patients. When anemia/hypoxia occurs, there is an increased expression of erythropoietin in renal peritubular interstitial fibroblast and, to a lesser extent, in hepatocytes and perisinusoidal fat-storing cells, which leads to stimulation of erythropoiesis [102]. Hepcidin in kidney and liver is produced in similar places. However, whether erythropoietin directly downregulates hepcidin expression remains to be conclusively proved [43]. Langsetmo et al. [103] have reported that FG-2216, a novel orally active inhibitor of HIF prolyl hydroxylases designated to activate HIF2-mediated natural erythropoietic cascade, increased hemoglobin, improved iron utilization (increased expression of iron transport proteins in the duodenum), and decreased hepcidin expression in the liver. In one more study of the same group, FG-2216 stimulated erythropoiesis by overcoming functional iron deficiency and inflammatory suppression [104].

In the study performed in hemodialyzed patients treated with erythropoietin, it was shown that serum prohepcidin was markedly increased in these patients when compared to the healthy volunteers [27] as well as patients with chronic renal failure [36]. All of their 59 hemodialyzed patients were treated 2-3 times a week with 3,000 IU erythropoietin. However, they did not provide even basal clinical characteristics of studied patients, not even hemoglobin level. They only stated that patients with renal anemia (a maximum hemoglobin concentration of $<11 \mathrm{~g} / \mathrm{dl}$ ) have significantly lower prohepcidin as compared to those with chronic renal insufficiency without anemia. No correlation between prohepcidin, iron status, ferritin and TSAT has been observed in their study [27]. We observed a significantly higher prohepcidin in non-anemic HD patients treated with erythropoietin $(\mathrm{Hb}>11 \mathrm{~g} / \mathrm{dl})$, but significantly lower ferritin and erythropoietin dose than in anemic hemodialyzed patients treated with erythropoietin [94]. In patients with CRP $\geq 6 \mathrm{mg} / \mathrm{l}$, prohepcidin was significantly higher than in patients with CRP $<6 \mathrm{mg} / \mathrm{l}$. In multiple regressions analysis, prohepcidin was independently related to albumin and triglycerides in the whole group of hemodialyzed patients but in the group of patients treated with erythropoietin in multiple regression analysis the only correlates of prohepcidin were hemoglobin and erythropoietin dose. These findings further stressed the role of liver in hepcidin synthesis as well as the link between inflammation and hepcidin in hemodialyzed patients. We concluded that elevated prohepcidin levels in hemodialyzed patients could be due to functional iron deficiency, anemia and low-grade inflammation [94]. Detivaud et al. [99] found that parameters reflecting the hepatic function were correlated with hepcidin levels. Serum albumin was positively related to hepcidin mRNA. In our study, albumin was, besides triglycerides, a correlate of prohepcidin in hemodialyzed patients. Similarly to the study of Detivaud et al. [99], we also did not find a relationship between hepcidin and CRP, probably due to the possible lack of CRP sensitivity for expressing inflammatory status in uremia and the presence of additional confounding regulatory factors.

In a study on 46 patients with chronic renal failure, who are not yet on dialysis, the serum hepcidin correlated with ${ }^{51} \mathrm{Cr}$-EDTA clearance $(\mathrm{r}=-0.44 ; \mathrm{p}=0.005)$, creatinine clearance, serum creatinine, $\beta$-trace protein and cystatin C [95]. However, the authors did not provide biochemical characteristics of the studied population, not even a mean serum creatinine. In contrast to our study, no relationship was found between red cell indices or iron status and serum prohepcidin concentrations [93]. Since significant correlations were observed between prohepcidin and kidney function, in the next study we focused on the role of kidney and residual renal function on prohepcidin metabolism [105]. Our data that creatinine and residual renal function in hemodialyzed patients and GFR in kidney transplant recipients are correlates of prohepcidin partly support this hypothesis. We concluded that elevated prohepcidin in patients with chronic kidney disease on hemodialysis and kidney allograft recipients may be due to low-grade inflammation (as reflected by prohepcidin correlations with hsCRP, albumin and ferritin), frequently encountered in this population and mainly to impaired renal function. High ferritin, a predictor of increased prohepcidin in kidney transplant recipients, may further support this suggestion. In another study on kidney transplant recipients, we reported that patients with coronary artery disease were older, had a higher prohepcidin, hsCRP, IL- 6 and TNF- $\alpha$, sTFR, ferritin, and lower cholesterol than patients without coronary artery disease [106]. Multiple regression analysis showed that prohepcidin was independently related to GFR (simplified MDRD), cholesterol, and hsCRP. We suggest that elevated hepcidin in kidney allograft recipients may be due not only to impaired renal function, but also to low-grade inflammatory state (as reflected by prohepcidin correlations with hsCRP, IL-6 and ferritin) [106]. 
There are only two papers on hepcidin and peritoneal dialysis presented in the abstract form $[107,108]$. In the former one [107], ferritin and prohepcidin were significantly higher in peritoneally dialyzed patients relative to healthy volunteers. Prohepcidin correlated positively with ferritin, iron, transferrin saturation, hsCRP and TNF- $\alpha$ and negatively with erythrocyte count, MCV in peritoneally dialyzed patients. In multiple regression analysis ferritin, hsCRP and TNF- $\alpha$ were predictors of prohepcidin in peritoneally dialyzed patients. Elevated prohepcidin levels in peritoneally dialyzed patients may be due to functional iron deficiency, low-grade inflammation and anemia. In the latter one, hepcidin levels, hsCRP, ferritin and erythropoietin requirements were higher in hemodialyzed patients when compared to peritoneal dialysis patients. Pertosa et al. [109] suggested that inflammation-related dysregulation of hepcidin expression might cause a functional iron deficiency and a subsequent erythropoietin hyporesponsiveness in uremic patients. They also noticed that peritoneal dialysis, by reducing the inflammatory response and hepcidin serum levels, dramatically improved response to erythropoietin.

\section{Measurement of Hepcidin}

Hepcidin-25 was initially identified in human blood using a mass spectrometric assay [26]. Then Park et al. [25] isolated urinary hepcidin-25 and hepcidin-20 using cation exchange chromatography and reverse-phase high-performance liquid chromatography. At present, there is no consensus on the best assay method for hepcidin, and assays for hepcidin detection and quantification in serum or urine have not been generally available. Questions have been raised about the relevance of prohepcidin levels to iron metabolism [109] as the mature form of hepcidin is the only one known to be biologically active. Measurement of prohepcidin level might be a limitation of some studies. However, there is still no reliable information available on normal serum levels of mature hepcidin (20, 22 and 25 amino acids), whereas 60 amino-acid prohepcidin is easily detectable in serum [27]. Assays for serum or urine hepcidin have not been generally available. The detection and quantification of hepcidin in plasma and serum have been hampered by technical difficulties (small size of hepcidin, limited availability of the antigen, isolation of hepcidin from urine involves complex, time-consuming procedures). Urine hepcidin assays seem to be preferable for studies on iron metabolism because serum hepcidin levels are below the detection limit of the currently used methods. This might be due to a quick clearance of free serum hepcidin by its binding to ferroportin and its subsequent cellular internalization [20]. Due to low molecular weight the remaining free hepcidin is efficiently filtered in the glomerulus. It could be also produced in the kidney. Thus, the urinary hepcidin excretion could be due to either to physiological incomplete reabsorption (overflow) or to impaired tubular reabsorption during chronic inflammation. Further research has now complicated the scenario. Urinary hepcidin-25 was detected in mice by immunodot assay [110, 111]. Nevertheless, Ganz [32] successfully developed an assay for detection and quantification of urinary hepcidin, but this assay seems to be available only in their laboratory. Recently, a new method for assay of urinary hepcidin- 25 by surface-enhanced laser desorption/ ionization time of flight mass spectrometry was reported [112]. However, measurement of urinary hepcidin is impossible in anuric dialyzed patients. Due to these limitations in hepcidin measurement, a commercially available assay for prohepcidin determination was used in some studies. To tackle and overcome the technical problems of hepcidin determination in dialyzed patients, Tomosugi et al. [101] recently employed the ProteinChip System to detect serum hepcidin in renal failure. A new technology, the surface-enhanced laser desorption/ionization time of flight mass spectrometry (SELDI-TOF MS) is based on classical solid-phase extraction chromatography combined with direct laser desorption/ionization mass spectrometric detection. SELDI-based ProteinChip System (Ciphergen Biosystes, Inc., Fremont, Calif., USA) array technology detects relevant biomarkers [113]. Tomosugi et al. [101] compared serum proteomic pattern with serum ferritin in hemodialysis patients in order to identify biomarkers associated with iron metabolism. They also developed a semiquantitative assay system to detect serum hepcidin-25. They found that in 2 hemodialysis patients, that they studied, the intensities of two peaks corresponding to hepcidin-20 and hepcidin-25 were higher than in healthy volunteers. These forms of hepcidin were sufficiently cationic to be filtered through the anionic glomerular membrane. They also reported that hepcidin-25 did not fall after the dialysis session in some patients. Tomosugi et al. [101] concluded that SELDI-TOF MS could be a clinically useful tool to detect and semiquantify bioactive serum hepcidin. However, as suggested by Pietrangelo and Trautwein [114], 'the reliability of methods must be proved (or disproved) by studies designed specifically for this purpose, and that validation 
requires that the assay (whether it uses blood or urine) can be transferred to, and reproduced in, different laboratories'.

\section{Future for Hepcidin}

Since overproduction of hepcidin plays a key role in the pathophysiology of anemia during inflammation and chronic disease, development of hepcidin antagonist would be possibly very useful for the treatment of this disease by facilitating iron redistribution from macrophages to erythroblasts. By blocking hepcidin, iron stores in the body could be mobilized, and hepcidin antagonists could also be used as a complement or instead of iron supplementation therapy. Hepcidin antagonists should be beneficial in the treatment of anemia of inflammation when the primary disease is refractory to therapy as well as when the anemia is not enough severe to warrant blood transfusion. Hepcidin antagonist may reverse the ironrestricted erythropoiesis contributing to anemia. In anemic patients with chronic kidney disease where erythropoietin synthesis is disturbed, a hepcidin antagonist might be useful as a supplement to ESA therapy, particularly for patients with a low response to them.

\section{References}

1 Brittenham GM: Disorders of iron metabolism: Iron deficiency and overload; in Hoffman R, Benz EJ Jr, Shattil SJ, et al (eds): Hematology Basic Principles and Practice, ed 2. New York, Churchill Livingstone, 1995.

2 Bridges KR, Seligman PA: Disorders of iron metabolism; in Handin RI, Lux SE, Stossel TP (eds): Blood: Principles and Practice of Hematology, chapt 49. Philadelphia, Lippincott, 1995.

$\checkmark 3$ Roy CN, Enns CA: Iron homeostasis: new tales from the crypt. Blood 2000;96:40204027.

4 Philpott CC: Molecular aspects of iron absorption: insights into the role of HFE in hemochromatosis. Hepatology 2002;35:9931001.

$\checkmark 5$ Finch CA, Huebers H: Perspectives in iron metabolism. N Engl J Med 1982;306:15201528.

-6 Bothwell TH: Overview and mechanisms of iron regulation. Nutr Rev 1995:53:237-245.

$\checkmark 7$ Cook JD: Clinical evaluation of iron deficiency. Semin Hematol 1982;19:6-18.

$>8$ Worwood M: Overview of iron metabolism at a molecular level. J Intern Med 1989;226: 381-391.

$\checkmark 9$ Deaglio S, Capobianco A, Cali A, Bellora F: Structural, functional, and tissue distribution analysis of human transferrin receptor2 by murine monoclonal antibodies and a polyclonal antiserum. Blood 2002;100:37823789.

-10 Robb A, Wessling-Resnick M: Regulation of transferrin receptor 2 protein levels by transferrin. Blood 2004;104:4294-4299.

- 11 Johnson MB, Enns CA: Diferric transferrin regulates transferrin receptor 2 protein stability. Blood 2004;104:4287-4293.

-12 Kawabata H, Nakamaki T, Ikonomi P, Smith RD: Expression of transferrin receptor 2 in normal and neoplastic hematopoietic cells. Blood 2001;98:2714-2719.
13 Hintze KJ, Theil EC: DNA and mRNA elements with complementary responses to hemin, antioxidant inducers, and iron control ferritin-L expression. Proc Natl Acad Sci USA 2005;102:15048-15052.

14 Torti FM, Torti SV: Regulation of ferritin genes and protein. Blood 2002;99:3505.

15 Finch CA, Bellotti V, Stray S, Lipschitz DA, Cook JD, Pippard MJ, Huebers HA: Plasma ferritin determination as a diagnostic tool West J Med 1986;145:657-663.

16 Abboud S, Haile DJ: A novel mammalian iron-regulated protein involved in intracellular iron metabolism. J Biol Chem 2000;275: 19906-19912.

17 Donovan A, Lima CA, Pinkus JL, Pinkus GS, Zon LI, Robine S, Andrews NC: The iron exporter ferroportin/Slc40al is essential for iron homeostasis. Cell Metab 2005;1:191200.

18 Chen H, Su T, Attieh ZK, Fox TC, McKie AT, Anderson GJ, Vulpe CD: Systemic regulation of hephaestin and Ireg1 revealed in studies of genetic and nutritional iron deficiency. Blood 2003;102:1893-1899.

19 Delaby C, Pilard N, Goncalves AS, Beaumont C, Canonne-Hergaux F: Presence of the iron exporter ferroportin at the plasma membrane of macrophages is enhanced by iron loading and down-regulated by hepcidin. Blood 2005;106:3979-3984.

20 Nemeth E, Tuttle MS, Powelson J, Vaughn MB, Donovan A, Ward DM, Ganz T, Kaplan $\mathrm{J}$ : Hepcidin regulates cellular iron efflux by binding to ferroportin and inducing its internalization. Science 2004;306:2090-2093.

$\checkmark 21$ Rivera S, Nemeth E, Gabayan V, Lopez MA, Farshidi D, Ganz T: Synthetic hepcidin causes rapid dose-dependent hypoferremia and is concentrated in ferroportin-containing organs. Blood 2005;106:2196-2199.
22 Delaby C, Pilard N, Goncalves AS, Beaumont C, Canonne-Hergaux F: The presence of the iron exporter ferroportin at the plasma membrane of macrophages is enhanced by iron loading and downregulated by hepcidin. Blood 2005;106:3979-3984.

23 Frazer DM, Anderson GJ: The orchestration of body iron intake: How and where do enterocytes receive their cues? Blood Cells Moll Dis 2003;30:288-297.

24 Andrews NC: Molecular control of iron metabolism. Best Pract Res Clin Haematol 2005;18:159-169.

25 Park CH, Valore EV, Waring AJ, Ganz T: Hepcidin, a urinary antimicrobial peptide synthesized in the liver. J Biol Chem 2001; 276:7806-7810.

26 Krause A, Neitz S, Magert HJ, Schyltz A, Forssmann WG, Schulz-Knappe P, Adermann L: LEAP-1, a novel highly disulfidebonded human peptide exhibits antimicrobial activity. FEBS Lett 2000;480:147-150.

27 Kulaksiz H, Gehrke SG, Janetzko A, Rost D, Bruckner T, Kallinowski B, Stremmel W: Pro-hepcidin: expression and cell specific localisation in the liver and its regulation in hereditary haemochromatosis, chronic renal insufficiency, and renal anaemia. Gut 2004; 53:735-743

28 Gunshin H, Mackenzie B, Berger UV, Gunshin Y, Romero MF, Boron WF, Nussberger S, Gollan JL, Hediger MA: Cloning and characterization of a mammalian proton-coupled metal-ion transporter. Nature 1997;388: 482-488.

29 Eschbach JW, Cook JD, Scribner BH, Finch CA: Iron balance in hemodialysis patients. Ann Intern Med 1977;87:710-713.

-30 Fernandez-Rodriguez AM, Guindeo-Casasus MC, Molero-Labarta T, Dominguez-Cabrera C, Hortal-Cascn L, Perez-Borges P, Vega-Diaz N, Saavedra-Santana P, Palop-Cubillo L: Diagnosis of iron deficiency in chronic renal failure. Am J Kidney Dis 1999;34:508-513. 
-31 Nissenson AR: Achieving target hematocrit in dialysis patients: new concepts in iron management. Am J Kidney Dis 1997;30:907911.

\$2 Ganz T: Hepcidin, a key regulator of iron metabolism and mediator of anemia of inflammation. Blood 2003;102:783-788.

-33 Nicolas G, Bennoun M, Devaux I, Beaumont C, Grandchamp B, Kahn A, Vaulont S: Lack of hepcidin gene expression and severe tissue iron overload in upstream stimulatory factor 2 knockout mice. Proc Natl Acad Sci USA 2001;98:8780-8785.

-34 Pigeon C, Ilyin G, Courselaud B, Leroyer P, Turlin B, Brissot P, Loreal O: A new mouse liver-specific gene, encoding a protein homologous to human antimicrobial peptide hepcidin, is overexpressed during iron overload. J Biol Chem 2001;276:7811-7819.

35 Hunter HN, Fulton DB, Ganz T, Vogel HJ: The solution structure of human hepcidin, a peptide-hormone with antimicrobial activity that is involved in iron uptake and hereditary hemochromatosis J Biol Chem 2002; 277:37597-37603.

>36 Kulaksiz H, Theilig F, Bachmann S, Gehrke SG, Rost D, Janetzko A, Cetin Y, Stremmel $\mathrm{W}$ : The iron-regulatory peptide hormone hepcidin: expression and cellular localization in the mammalian kidney. J Endocrinol 2005;184:361-370.

\37 Nicolas G, Bennoun M, Porteu A, Mativet S, Beaumont C, Grandchamp B, Sirito M, Sawadogo M, Kahn A, Vaulont S: Severe iron deficiency anemia in transgenic mice expressing liver hepcidin. Proc Natl Acad Sci USA 2002;99:4596-4601.

\38 Nicolas G, Viatte L, Lou DQ, Bennoun M, Beaumont C, Kahn A, Andrews NC, Vaulont $S$ : Constitutive hepcidin expression prevents iron overload in a mouse model of hemochromatosis. Nat Genet 2003;34:97-101.

-39 Laftah AH, Ramesh B, Simpson RJ, Solanky N, Bahram S, Schumann K, Debnam ES, Srai SK: Effect of hepcidin on intestinal iron $\mathrm{ab}$ sorption in mice. Blood 2004;103:39403944.

40 Nemeth E, Rivera S, Gabayan V, Keller C, Taudorf S, Pedersen BK, Ganz T: IL-6 mediates hypoferremia of inflammation by inducing the synthesis of the iron regulatory hormone hepcidin. J Clin Invest 2004;113: 1271-1276.

-41 Ganz T: Hepcidin - a regulator of intestinal iron absorption and iron recycling by macrophages. Best Pract Res Clin Haematol 2005;18:171-182.

42 Nicolas G, Chauvet C, Viatte L, Danan JL, Bigard X, Devaux I, Beaumont C, Kahn A, Vaulont S: The gene encoding the iron regulatory peptide hepcidin is regulated by anemia, hypoxia, and inflammation. J Clin Invest 2002;110:1037-1044.

43 Nicolas G, Viatte L, Bennoun M, Beaumont C, Kahn A, Vaulont S: Hepcidin a new iron regulatory peptide. Blood Cells Mol Dis 2002;29:327-335
44 Safran M, Kaelin WG Jr: HIF hydroxylation and the mammalian oxygen-sensing pathway. J Clin Invest 2003;111:779-783.

45 Courselaud B, Pigeon C, Inoue Y, Inoue J, Gonzalez FJ, Leroyer P, Gilot D, Boudjema K, Guguen-Guillouzo C, Brissot P, Loreal O, Ilyin G: $\mathrm{C} / \mathrm{EBP}-\alpha$ regulates hepatic transcription of hepcidin, an antimicrobial peptide and regulator of iron metabolism. J Biol Chem 2002;277:41163-41170.

46 Roy CN, Andrews NC: Anemia of inflammation: the hepcidin link. Curr Opin Hematol 2005;12:107-111.

47 Roetto A, Papanikolaou G, Politou M, Alberti F, Girelli D, Christakis J, Loukopoulos D, Camaschella C: Mutant antimicrobial peptide hepcidin is associated with severe juvenile hemochromatosis. Nat Genet 2003;33: 21-22.

48 Morley JJ, Kushner I: Serum C-reactive protein levels in disease. Ann NY Acad Sci 1982; 389:406-418.

49 Kushner I: The phenomenon of the acute phase response. Ann NY Acad Sci 1982;389: 39-48.

50 Gabay C, Kushner I: Acute-phase proteins and other systemic responses to inflammation. N Engl J Med 1999;340:448-454.

51 Nemeth E, Valore EV, Territo M, Schiller G, Lichtenstein A, Ganz T: Hepcidin, a putative mediator of anemia of inflammation, is a type II acute-phase protein. Blood 2003;101: 2461.

52 Shike H, Lauth X, Westerman ME, Ostland VE, Carlberg JM, van Olst JC, Shimizu C, Bulet P, Burns JC: Bass hepcidin is a novel antimicrobial peptide induced by bacterial challenge. Eur J Biochem 2002;269:22322237.

53 Gauldie J, Richards C, Harnish D, Lansdorp $\mathrm{P}$, Baumann $\mathrm{H}$ : Interferon- $\beta_{2} / \mathrm{B}$-cell stimulatory factor type 2 shares identity with monocyte-derived hepatocyte-stimulating factor and regulates the major acute phase protein response in liver cells. Proc Nat Acad Sci USA 1987;84:7251-7255.

54 Moshage HJ, Janssen JA, Franssen JH, Hafkenscheid JC, Yap SH: Study of the molecular mechanisms of decreased liver synthesis of albumin in inflammation. J Clin Invest 1987;79:1635-1641.

55 Wrighting DM, Andrews NC: Interleukin-6 induces hepcidin expression through STAT3. Blood 2006;108:3204-3209.

56 Kemna E, Pickkers P, Nemeth E, van der Hoeven H, Swinkels D: Time course analysis of hepcidin, serum iron, and plasma cytokine levels in human injected with LPS. Blood 2005;106:1864-1866.

57 Aisen P, Enns C, Wessling-Resnick M: Chemistry and biology of eukaryotic iron metabolism. Int J Biochem Cell Biol 2001;33: 940-959.

58 Dey R, Datta SC: Leishmanial glycosomes contain superoxide dismutase. Biochem J 1994;301:317-319.
59 Zhang Y, Lathigra R, Garbe T, Catty D, Young D: Genetic analysis of superoxide dismutase, the 23 kilodalton antigen of mycobacterium tuberculosis. Mol Microbiol 1991; 5:381-391.

60 Singh PK, Parsek MR, Greenberg EP, Welsh MJ: A component of innate immunity prevents bacterial biofilm development. Nature 2002;417:552-555.

61 Risso A: Leukocyte antimicrobial peptides: multifunctional effector molecules of innate immunity. J Leukoc Biol 2000;68:785-792.

-62 Yang D, Biragyn A, Hoover DM, Lubkowski J, Oppenheim JJ: Multiple roles of antimicrobial defensins, cathelicidins, and eosinophilderived neurotoxin in host defense. Annu Rev Immunol 2004;22:181-215.

63 Ashrafian H: Hepcidin: the missing link between hemochromatosis and infections. Infect Immun 2003;71:6693-6700.

64 Xiong S, She H, Takeuchi H, Han B, Engelhardt JF, Barton CH, Zandi E, Giulivi C, Tsukamoto H: Signaling role of intracellular iron in NF- $\kappa \mathrm{B}$ activation. J Biol Chem 2003; 278:17646-17654.

65 Lee P, Peng H, Gelbert T, Beutler E: The IL-6 and lipopolysaccharide-induced transcription of hepcidin in HFE-transferrin receptor 2 - and $\beta_{2}$-microglobulin-deficient hepatocytes. Proc Natl Acad Sci USA 2004;101: 9263-9265.

66 Weinstein DA, Roy CN, Fleming MD, Loda MF, Wolfsdorf JI, Andrews NC: Inappropriate expression of hepcidin is associated with iron refractory anemia: implications for the anemia of chronic disease. Blood 2002;100: 3776-3781.

67 Andrews NC: Anemia of inflammation: the cytokine-hepcidin link. J Clin Invest 2004; 113:1251-1253.

68 Cash JM, Sears DA: The anemia of chronic disease: spectrum of associated diseases in a series of unselected hospitalized patients. Am J Med 1989;87:638-644.

69 Schilling RF: Anemia of chronic disease: a misnomer. Ann Intern Med 1991;115:572573.

70 Weiss G: Pathogenesis and treatment of anaemia of chronic disease. Blood Rev 2002; 16:87-96.

71 Means RT Jr: Recent developments in the anemia of chronic disease. Curr Hematol Rep 2003;2:116-121.

72 Weiss G, Goodnough LT: Anemia of chronic disease. N Engl J Med 2005;352:1011-1023.

73 Opasich C, Cazzola M, Scelsi L, et al: Blunted erythropoietin production and defective iron supply for erythropoiesis as major causes of anaemia in patients with chronic heart failure. Eur Heart J 2005;26:22322237.

74 Fleming RE, Sly WS: Hepcidin: a putative iron-regulatory hormone relevant to hereditary hemochromatosis and the anemia of chronic disease. Proc Natl Acad Sci USA 2001;98:8160-8162. 
75 Dallalio G, Law E, Means T: Hepcidin inhibits in vitro erythroid colony formation at reduced erythropoietin. Blood 2006;107:27022704.

76 Katsume A, Saito H, Yamada Y: Anti-interleukin-6 (IL-6) receptor antibody suppresses Castleman's disease like symptoms emerged in IL-6 transgenic mice. Cytokine 2002;20: 304-311.

-77 Van Gameren MM, Willemse PH, Mulder $\mathrm{NH}$ : Effects of recombinant human interleukin-6 in cancer patients a phase I-II study. Blood 1994;84:1434-1441.

-78 Nieken J, Mulder NH, Buter J, Vellenga E, Limburg PC, Piers DA, de Vries EG: Recombinant human interleukin- 6 induces a rapid reversible anemia in cancer patients. Blood 1995;86:900-905.

-79 Schindler R, Boenisch O, Fischer C, Frei U: Effect of the hemodialysis membrane on the inflammatory reaction in vivo. Clin Nephrol 2000;53:452-459.

$>80$ Memoli B, Minutolo R, Bisesti V, Postiglione L, Conti A, Marzano L, Capuano A, Andreucci M, Balletta MM, Guida B, Tetta C, Collaborative Study Group on SMC Membrane: Changes of serum albumin and C-reactive protein are related to changes of interleukin-6 release by peripheral blood mononuclear cells in hemodialysis patients treated with different membranes. Am J Kidney Dis 2002;39:266-273.

-81 Tielemans C, Husson C, Schurmans T, Gastaldello K, Madhoun P, Delville JP, Marchant A, Goldman M, Vanherweghem JL: Effects of ultrapure and non-sterile dialysate on the inflammatory response during in vitro hemodialysis. Kidney Int 1996;49:236243.

82 Hosoya N, Sakai K: Backdiffusion rather than backfiltration enhances endotoxin transport through highly permeable dialysis membranes. ASAIO Trans 1990;36:M311.

$>83$ Ayus JC, Sheikh-Hamad D: Silent infection in clotted hemodialysis access grafts. J Am Soc Nephrol 1998;9:1314-1317.

-84 Cappelli G, Tetta C, Canaud B: Is biofilm a cause of silent chronic inflammation in haemodialysis patients? A fascinating working hypothesis. Nephrol Dial Transplant 2005; 20:266-270.

85 Bemelmans MH, Gouma DJ, Buurman WA: Influence of nephrectomy on tumor necrosis factor clearance in a murine model. J Immunol 1993;150:2007-2017.

>86 Poole S, Bird TA, Selkirk S, Gaines-Das RE, Choudry Y, Stephenson SL, Kenny AJ, Saklatvaa J: Fate of injected interleukin-1 in rats: sequestration and degradation in the kidney. Cytokine 1990;2:416-422.

87 Panichi V, Migliori M, De Pietro S, Taccola D, Bianchi AM, Norpoth M, Metelli MR, Giovannini L, Tetta C, Palla R: C-reactive protein in patients with chronic renal diseases. Ren Fail 2001;23:551-562.
-88 Stenvinkel P, Heimburger O, Wang T, Lindholm B, Bergstrom J, Elinder CG: High serum hyaluronan indicates poor survival in renal replacement therapy. Am J Kidney Dis 1999;34:1083-1088.

89 Chung SH, Heimburger O, Stenvinkel P, Bergstrom J, Lindholm B: Association between inflammation and changes in residual renal function and peritoneal transport rate during the first year of dialysis. Nephrol Dial Transplant 2001;16:2240-2245.

$\$ 90$ Pecoits-Filho R, Heimburger O, Barany P, Suliman M: Associations between circulating inflammatory markers and residual renal function in CRF patients. Am J Kidney Dis $2003 ; 41: 1212-1218$.

91 Ross R: Atherosclerosis: an inflammatory disease. N Engl J Med 1999;340:115-126.

$\$ 92$ Shah SV, Alam MG: Role of iron in atherosclerosis. Am J Kidney Dis 2003;41(suppl 1):S80-S83.

$\checkmark 93$ Allen DA, Breen C, Yaqoob MM, Macdougall IC: Inhibition of CFU-E colon formation in uremic patients with inflammatory disease. Role of IFN- $\gamma$ and TNF- $\alpha$. J Investig Med 1999;47:204-211.

94 Malyszko J, Malyszko JS, Hryszko T, Pawlak K, Mysliwiec M: Is hepcidin a link between anemia, inflammation and liver function in hemodialyzed patients? Am J Nephrol 2005;25:586-590.

$\checkmark 95$ Taes YE, Wuyts B, Boelaert JR, De Vriese AS, Delanghe JR: Prohepcidin accumulates in renal insufficiency. Clin Chem Lab Med 2004;42:387-389.

$\$ 96$ Dallalio G, Fleury T, Means T: Serum hep cidin in clinical specimens. Br J Haematol 2003;122:996-1000.

-97 Sunder-Plassmann G, Horl WH: Erythropoietin and iron. Clin Nephrol 1997;47: 141-157.

-98 Gauldie J, Richards C, Harnish D, Lansdorp P, Baumann $\mathrm{H}$ : Interferon- $\beta_{2} / \mathrm{B}$-cell stimulatory factor type 2 shares identity with monocyte-derived hepatocyte-stimulating factor and regulates the major acute phase protein response in liver cells. Proc Natl Acad Sci USA 1987;4:7251-7255.

99 Detivaud L, Nemeth E, Boudjema K, Turlin B, Troadec MB, Leroyer P, Ropert M, Jacquelinet S, Courselaud B, Ganz T, Brissot P, Loreal O: Hepcidin levels in humans are correlated with hepatic iron stores, hemoglobin levels and hepatic function. Blood 2005;106:746-748.

100 Aoki CA, Rossaro L, Ramsamooj RR, Brandhagen D, Burritt MF, Bowlus CL: Liver hepcidin mRNA correlates with iron stores, but not inflammation, in patients with chronic hepatitis C. J Clin Gastroenterol 2005;39:71-74.

101 Tomosugi N, Kawabata H, Wakatabe R, et al: Detection of serum hepcidin in renal failure and inflammation by using ProteinChip System. Blood 2006;108:13811387.
102 Wang GL, Semenza GL: Molecular basis of hypoxia-induced erythropoietin expression. Curr Opin Hematol 1996;3:156-162.

103 Langsetmo I, Nichols B, Seeley T, Stephenson B, Klaus S, Lin A, Liu DY: FG-2216 corrects anemia and improves iron utilization in a rat model of anemia of chronic disease: comparison to darbepoetin. J Am Soc Nephrol 2005;16:481A.

104 Seeley TW, Langsetmo I, Stephenson R, Pacleb J, Gervasi D, Lomonsgod E, Klaus S, Liu DY: FG-2216: Tumor progression studies and correction of anemia of chronic disease in xenograft model. J Am Soc Nephrol 2005;16:481A.

105 Malyszko J, Malyszko JS Pawlak K, Mysliwiec M: Hepcidin, iron status and renal function in chronic renal failure, kidney transplantation and hemodialysis. Am J Hematol 2006;81:832-837.

106 Malyszko J, Malyszko JS Pawlak K, Mysliwiec M: Hepcidin, an acute phase protein and a marker of inflammation in kidney transplant recipients with and without coronary artery disease. Transplant Proc 2006, doi 10.1016/jtransproceed. 2006.06.137

107 Brookes MJ, Sharma NK, Tselepis C, Iqbal $\mathrm{TH}$ : Serum pro-hepcidin: measuring active hepcidin or a non-functional precursor? Gut 2005;54:169-170.

108 Malyszko J, Malyszko JS, Pawlak K, Brzosko S, Rams L, Mysliwiec M: Hepcidin: a link between anemia and inflammation peritoneally dialyzed patients? ISPD Congress, Hong Kong 2006, p 377.

109 Pertosa G, Simone S, Corciulo R, Pontrelli $P$, et al: Hepcidin serum levels, functional iron deficiency and erythropoietin hyporesponsiveness in hemodialysis and peritoneal dialysis. J Am Soc Nephrol 2005;16: 476A.

110 Papanikolaou G, Tzilianos M, Christakis JI, Bogdanos D, Tsimirika K, MacFarlane J, Goldberg YP, Sakellaropoulos N, Ganz T, Nemeth E: Hepcidin in iron overload disorders. Blood 2005;105:4103-4105.

111 Rivera S, Liu L, Nemeth E, Gabayan V, Sorensen OE, Ganz T: Hepcidin excess induces the sequestration of iron and exacerbates tumor-associated anemia. Blood 2005;105: 1797-1802.

112 Kemna E, Tjalsma H, Laarakkers C, Nemeth E, Willems H, Swinkels D: Novel urine hepcidin assay by mass spectrometry. Blood 2005;106:3268-3270.

113 Tomosugi N, Kitagawa K, Takahashi N, Sugai S, Ishikawa I: Diagnostic potential for a tear proteonomic patterns in Sjögren's syndrome. J Proteosome Res 2005;4:820825.

114 Pietrangelo A, Trautwein C: Mechanisms of disease: the role of hepcidin in iron homeostasis - implications for hemochromatosis and other disorders. Nat Clin Practice Gastrol Hepatol 2004; 1:39-45; authors' reply 2005;2:E2 doi 10.1038/ncpgasthep 0122 . 